\title{
FEDERAL RULE OF CIVIL PROCEDURE 24(a)(2) AND THE "INTEREST" NECESSARY FOR INTER VENTION AS OF RIGHT ON APPEAL
}

In Smuck v. Hobson the Court of Appeals for the District of Columbia Circuit held that parents of school children were entitled to intervene as of right under Federal Rule of Civil Procedure 24(a)(2) to appeal a district court's school desegregation order which the parents contended limited the local school board's discretion even though the school board did not appeal. The original action was brought on behalf of Negro and poor children against the school board for unconstitutionally denying members of their class equal educational opportunities." ln order to eliminate racial and economic status discrimination, the district court issued specific orders requiring the school board to eliminate optional zones in which students could choose which of two schools they wished to attend; to provide transportation for volunteering students from overcrowded schools to those with excess capacity; and immediately provide for substantial faculty integration. The district court also issued a general injunction against racial or economic discrimination by the school board; required it to submit a long-range plan of pupil assignment designed to alleviate racial imbalance; and ordered termination of the "track system," an allegedly discriminatory method of grouping students of comparable scholastic ability. The school board voted six to two to accept the district court ruling and indicated compliance. The Superintendent of Schools, a named defendant in the original action, ${ }^{t}$ resigned his position but, nevertheless, appealed. Presumably recognizing that his right to appeal as a named defendant was lost when he resigned his official position, the Superintendent, along with one of the dissenting school board members and parents of certain school children, sought to intervene

\footnotetext{
1408 F.2d 175 (D.C. Cir. 1969).

: Hobson v. Hansen, 269 F. Supp. 401 (D.D.C. 1967), appual dismissed 393 U.S. 801 (1968).

$=$ Id. at $517-18$.

I ld. at 401 .
} 
under rule $24(a)(2)$ to appeal the district court's order on the ground that it was unreasonably restrictive of the school board's discretion. After a hearing at the request of the court of appeals, the district court reluctantly granted intervention as of right to all three applicants solely for the purpose of setting the stage for a test of this right at the appellate level..$^{5}$ The court of appeals reversed with regard to the former superintendent, holding that he had no standing to appeal after he left his official position and did not have the necessary interest to intervene since a decision on the appeal would have no effect on him individually. The dissenting member of the school board was similarly denied the right to intervene because his official interest was limited to his right to participate in school board decisions, and he also was without an individual interest. The parents were held to have an interest sufficient for intervention under 24(a)(2) for the limited purpose of challenging those portions of the district court order which did in fact limit the school board's discretion. Because the orders enjoining discrimination and requiring the formulation of the long range pupil assignment plan merely declared constitutional requirements and because the order to abolish the "track system" left the board free to devise a more equitable system of ability grouping, the parents were found to have no interest to permit intervention as to these orders since they did not impair the board's discretion. Conversely, the court found that the orders requiring bussing of volunteering students, faculty integration, and elimination of optional zones did limit the board's discretion in areas of immediate concern to the parents and their children, and intervention to appeal them was granted. The appeal, however, was denied on the merits, the court of appeals holding that the orders limiting the board's discretion were constitutionally required in order to correct segregative practices in the school system. The decree was thus left unaltered by appeal, but the case was remanded to allow the district court to insure the newly elected school board full freedom in implementing the decree.

The present version of rule 24(a) is the product of a 1966 revision which broadened the right of intervention by combining the

\footnotetext{
5 Hobson v. Hansen, 44 F.R.D. 18 (D.D.C. 1968), notcel in 17 Catholic U.L. Rev. 495 (1968).
} 
basic ideas of former subsections (2) and (3). ${ }^{6}$ Old subsection (3) provided for the intervention of individuals who might be adversely affected by a court's disposition of property, ${ }^{7}$ but that type of intervention was infrequently grantcd unless the applicant claimed an interest in a fund under court control. ${ }^{\text {" Intervention under }}$ former subsection (2), which required that an applicant be "bound" by judgment in the action as well as inadequately represented by existing parties, ${ }^{9}$.was made similarly unavailable to most prospective intervenors when the Supreme Court held that the applicant must show that judgment in the main action would later subject him to a plea of res judicata. ${ }^{10}$ Discarding any requirement that an applicant claim ownership of a fund or that he be bound by res judicata," present rule 24(a)(2) requires that an individual be permitted to intervene

when the applicant claims an interest relating to the property or transaction which is the subject of the action and he is so situated that the disposition of the action may as a practical matter impair or impede his ability to protect that interest, unless the applicant's interest is adequately represented by existing parties.'2

Shortly after the effective date of the new rule, the Supreme Court in Cascade Natural Gas Corp. v. El Paso Natural Gas Co.":3 granted intervention as of right to a purchaser of natural gas on the

Fi:D. R. Civ. P. 24(a)(2); Rule 24(a)(1), unchanged by the 1966 amendment, provides for intervention "when a statute of the United States provides an unconditional right to intervene."

7 FED. R. CIV. P. 24(a)(3), 329 U.S. 853 (1946).

* See Allen Calculators, Inc. v. Nat'1 Cash Register Co., 322 U.S. 137 (1944): United States v. ASCAP. 202 F. Supp. 340 (S.D.N.Y. 1962). But see Formulabs, Inc. v. Hartley Pen Co., 275 F.2d 52 (9th Cir.), cert. denied. 363 U.S. 830 (1960). See generally 2 W. Barrox A. Holtzorf, Fiperal. Practice a.id Proceldure $\$ 598$ (IVtight ed. 1961): 4 J. Muore. Flidi:Ral. Practicl: 24.09 (2d ed. 1968).

- FED. R. CIV. P. $24(\mathrm{a})(2), 329$ U.S. 853 (1946).

"S Sam Fox Publishing Co. v. United States. 366 U.S. $683.690-93$ (1961). See genterall! Comment. Intervention of Right in Class Actions: The Dilemna of Federal Rule of (ivil Procedure 24(a)(2), 50 CALtt. L. Ri:v. $\$ 9$ (1962).

"Sec Advisory Committee's Note. 39 F.R.D. 69. 109-11 (1966).

IE Fis. R. Civ. P. 24(a)(2). Although traditionally the burden of showing that the requirements of the rule are met is on the intervenor. the addition of the term "unless" in the 1966 amendment has suggested to some courts that the applicant has only the burden of" showing an interest which may be impaired by the court's holding; the burden of showing adequate representation thus shifting to the party opposing intervention. See Vuesse v. Camp, 385 F.2d 694 (D.C. Cir. 1967): Peterson v. United States, 41 F.R.D. I31 (D. Minn. 1966). See gentrall! + J. MoOrl: Fideral. Practic!: 24.08 (2d ed. 1968).

$r=386$ U.S. 129 (1967). 
basis of his economic interest in a divestiture decree which the intervenor claimed left his sole supplier of natural gas in a weakened economic position. ${ }^{14}$ Broadly interpreted, El Paso would seem to open the route of intervention to countless customers and competitors asserting an economic interest in antitrust litigation. Nevertheless, the unique circumstances of the El Paso case, and the court's dicta therein, have led many commentators to the conclusion that it is not a substantial expansion of rule 24(a)(2).'. In El Paso the Supreme Court may well have permitted intervention as a means of ultimately bringing the divestiture decree in line with its earlier mandate. Also, the lengthy dicta on the defects of the decree indicate that the court obviously felt that the public interest had not been adequately represented. The view that El Paso should be limited by these factors is further supported by the Court's dismissal without opinion of another application to intervene to challenge an antitrust consent decree. In Lupton Manufacturing C ${ }^{\circ}$. $v$. United States ${ }^{15}$ the intervenor. asserted an economic interest comparable to that shown in El Paso. but the lower court denied intervention on a showing that the Government had diligently protected the public interest. Therefore, there seems to be a serious question whether the Supreme Court's ruling in $E l$ Paso was designed to expand the "interest" concept of rule $24(a)(2)$ to the extent suggested by a literal reading of the opinion or merely to allow intervention to insure compliance with its prior decision.

Post-El Paso decisions in the lower federal courts have done little to define the scope of the "interest" required for intervention. Several such decisions have found ${ }^{17}$ or refused to find ${ }^{1 x}$ an

"Id. at 133.

I5 K.g.. Note. Federal Civil Procedure: Intervention of Right Granted Privatc Part! in Government Antitrust Suit Under New Rule 24(a)(2), 1968 Duke L.J. 117; The Supreme Court. 1966 Term. 81 HARv. L. REv. 110, $221-25$ (1967). See also Kaplan. Continuing Work of the Civil Committee: 1966 Amendmemts of the Federal Rules of Cistl Procedure, 81 HaRv. L. Rev. 356, 406 (1968) (calling Ei Paso "questionable procedural law").

"s 388 U.S. 457, dismissing appeal Jrom United States v. Aluminum Co. of America. 41 F.R.D. 342 (E.D. MO. 1967).

ī E.g.. Atlantis Dev. Corp. v. United States, 379 F.2d 818 (5th Cir. 1967) (interest was claim to ownership); Peterson v. United States, 41 F.R.D. 131 (D. Minn. 1966) (interest was remainderman's share of trust fund).

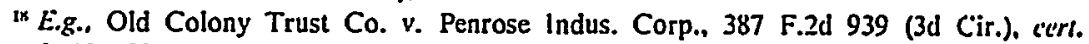
denied, 392 U.S. 927 (1968) (speculative interest in property is not sufficient under rule 
"interest" based on the "property" concept so frequently used in pre-amendment cases. A similar pre-amendment concept of "interest" was used to deny intervention on the grounds that there was no legal detriment to the intervenor flowing from the decision..$^{19}$ Generally, those decisions which have considered an "economic" interest similar to that in El Paso have been unwilling to find a similarly broad right of intervention. In Isbrandtsen Co. v. S.S. Kokoh Maru, ${ }^{20}$ a district court held an intervenor must have a "direct personal or pecuniary interest in the subject of the litigation" but refused to allow a plaintiff seeking to recover the purchase price of goods to intervene in an action brought by the defendant against the carrier for damages to the goods. A broad reading of El Paso's interest concept was also rejected by the Third Circuit which refused to allow a prospective purchaser to intervene in a suit for declaratory judgment to determine the commercial reasonableness of a proposed sale of pledged collateral under section 9-507(2) of the Uniform Commercial Code.2t In Linited States v. First National Bank \& Trust Co..22 a district court relied on El Paso to allow intervention by a competing bank to contest a proposed final judgment allowing a merger of rival banks. However, the court specifically adopted the interpretation of $E l$ Paso advanced by Mr. Justice Stewart's dissent'23 - that of allowing intervention when a volunteer could convince the court that the Government might have used bad judgment in conducting or settling the lawsuit. The lone exception to the trend toward restricting the El Paso holding has been the District of Columbia Circuit's decision in Vuesse v. Camp." $\ln$. Vuesse, a state official directly concerned with effectuating a state banking policy was allowed to intervene in a federal action involving interpretation of federal banking regulations which were largely reflective of state

24(a)(2): United States v. Benford. 44 F.R.D. 231 (N.D. Ind. 1968) (real interest is title to documents and not the alleged interest of possible use of the principal judgment in subsequent criminal prosecution).

10 Edmondson v. State ex rel. Meyer, 383 1..2d 123 (8th Cir. 1967).

50 263 F. Supp. 784 (S.D.N.Y. 1966).

" Old Colony Trust Co. v. Penrose Indus. Corp., 387 F.2d 939 (2d Cir.), cert. denied. 392 U.S. 927 (1968).

$=280$ F. Supp. 260 (E.D. Ky. 1967). affd. 391 U.S. 469 (1968).

$=$ Cascade .Vatural Gas Corp. v. El Paso Natural Gas Co.. 386 U.S. 129, 143 (1967) (Stewart, J.. dissenting).

$=385$ F.2d 694 (D.C. Cir. 1967). 
banking regulations. The state official's "interest" derived from the fact that the potential interpretation of federal regulations could be out of harmony with state regulation interpretation. Such disparity might put state banks at a disadvantage in competing with national banks. The Nuesse court broadly defined the interest test as "a practical guide to disposing of lawsuits by involving as many apparently concerned persons as is compatible with efficiency and due process." ${ }^{25}$

More prominent in the post-El Paso decisions than a broad reading of the "interest" requirement has been a focusing on the two other tests enunciated by rule 24(a)(2)- "practical impairment or impediment" and "adequacy of representation." The leading case on the nature of "practical impairment" is Atlantis Development Corp. v. United States ${ }^{26}$ involving intervention by a person claiming title to certain reefs in a suit brought by the Government against other claimants to the reefs. The court recognized that although judgment in the main action would not be res judicata as to the proposed intervenor, a favorable judgment for the Government would likely represent a legal precedent adverse to the intervenor's claim. Therefore, under new rule 24(a)(2), the potential effect of stare decisis was found to create the requisite "practical impairment." The Atlantis rationale was approved and followed in Nuesse where the court spoke of the revised federal rules being designed to avoid a "fragmented approach to adjudication." ${ }^{2 i}$ The traditional concept of inadequacy of representation, the third test of rule 24(a)(2), was summarized by the court in Peterson v. Lnited States $^{28}$ as representation which involved collusion, an adverse interest, or a failure to fulfill a duty. However, a recent decision, United States v. Blue Chip Stamp Co. ${ }^{29}$ recognized that inadequate representation of a proposed intervenor's interest may arise from the decision of an original party not to appeal an adverse decision.

= Id. at 700 .

$=6379$ F.2d 818 (5th Cir. 1967).

$=385$ F.2d 694, 702 (D.C. Cir. 1967). But see Old Colony Trust Co. v. Penrose Indus. Corp., 387 F.2d 939 (3d Cir.), cert. denied. 392 U.S. 927 (1968) (intervention denied to one who sought to attack commercial reasonableness of proposed sale which was the subject of the main litigation).

* 41 F.R.D. 131 (D. Minn. 1966).

272 F. Supp. 432, 437 (C.D. Cal. 1967), affd sub nom.. Thrifty Shoppers Script Co. v. United States, 389 U.S. 580 (1968). For a similar pre-amendment ruling, sev Woipe v. Poretsky. 144 F.2d 505 (D.C. Cir.), cert. denied. 323 U.S. 777 (1944). 
-Vuesse also liberalized the scope of adequacy of representation by holding that the difference between a public interest advanced by a proposed intervenor and a private interest of the original party would create an inadequacy. ${ }^{30}$ Therefore, while most lower federal courts have been unwilling to expand the "interest" required by 24(a)(2) to the extent suggested by a literal reading of El Paso. there have been significant advances in expanding the concepts of "practical impairment" and "adequate representation."

Although liberally construing the interest requirement, the court in Smuck v. Hobson denied intervention to the resigned Superintendent and to the dissenting school board members for their failure to show an interest. As a named defendant only in his official capacity, the Superintendent after resigning was without any personal interest and would not be personally bound by the outcome of the action. ${ }^{31}$ Similarly, the dissenting board member, although retaining his official position, had no personal interest since he had full opportunity to participate in the school board's defense and its decision not to appeal, and since he as an individual could not violate the decree or be subject to enforcement proceedings. ${ }^{32}$ However, the parents' concern for their children's education was recognized by the court as a legally protected interest on the basis of cases granting standing to sue founded on comparable interests. ${ }^{33}$ The court realized that the question regarding intervention was not whether the party could bring a suit but whether he should be allowed to participate in litigation already in progress. Citing its test in . Viesse, the court reiterated its view of the interest requirement as a "guide to disposing of lawsuits by involving as many apparently concerned persons as is compatible with efficiency and due process." "Relying on El Paso as formulating an expansive concept of "interest," the Smuck court found that under certain circumstances, the parents' concern for

$\Rightarrow 385$ F.2d 694 (D.C. Cir. 1967). See text accompanying note 25 supra.

s 408 F.2d at 177. Presumably this rationale would have applied to the former Superintendent even if he had retained his position due to the decision of the board not to appeal. But see Nuesse v. Camp, 385 F.2d 694 (D.C. Cir. 1967).

${ }^{2} 408$ F.2d at 178. See State ex rel. Erb v. Sweaas, 98 Minn. 17, 107 N.W. 404 (1906); Elterich v. Andt, 175 Wash. 562, 27 P.2d 1102 (1933).

$\geq 408$ F.2d at 178-79. See, e.g., Pierce v. Society of Sisters, 268 U.S. 510, 534-35 (1925).

3t 408 F.2d at 179, quoting Nuesse v. Camp, 385 F.2d 694, 700 (D.C. Cir. 1967). 
their children's education was sufficient "interest" under the test advanced by Nuesse. ${ }^{35}$.

In determining whether the circumstances justifying intervention were present, the second and third requirements of "practical impediments" and "inadequate representation" were found to be more useful in limiting the extension of intervention than was the "interest" requirement. ${ }^{36}$ Stare decisis would provide the practical impairment since if not allowed to intervene, the parents had no way to pursue their interest unless they alleged that the policies adopted by the board were unconstitutional. But while such policies might not be constitutionally required, the very discretion for which the parents were arguing would give the board wide range in adopting such policies without encountering constitutional objections. ${ }^{37}$ lmplicit in this rationale is the assumption that mandamus would not lie to compel school board action; not only because it is an extraordinary writ, but also because its use is limited to compelling required acts, not to challenging an act of discretion. ${ }^{38}$ The court tacitly assumed that the parents' interests were adequately represented by the defendants at trial. However, the conflict between the interests of the school board representing all parents in the District and the narrower interest of the proposed intervenors in their own children could have caused inadequate representation since considerations such as publicity, cost, and delay would not have the same inhibiting effect on the parents as it might have on the school board. Moreover, the court noted that even an overly restrictive court order might be welcome relief to a school board buffetted by opposing demands and in search of another scapegoat. ${ }^{39}$ Therefore, the intervenors established a sufficiently serious possibility that they were inadequately represented on the decision not to appeal.

Having decided that the parents would be practically disadvantaged by not permitting an appeal and that their representation by existing parties was inadequate so that all requirements for intervention were present, a more thorough

\footnotetext{
$=408$ F.2d at $179-80$.

$=5$ Id. at 179.

$=\mathrm{Id}$. at $180-81$.

:x See. e.g.. Panama Canal Co. v. Grace Line, Inc., 356 U.S. 309, 317-18 (1958):

Virginian Ry. v. System Fed'n 40, AFL, 300 U.S. 515,551 (1937).

39 408 F.2d at 181 .
} 
analysis of their "interest" was necessary to determine the scope of intervention to be granted." Since their interest was only in allowing the board the widest discretion possible, the parents were allowed to intervene only to contest those issues which imposed actual restraints upon the board." The court viewed the ruling on the long-range plan of pupil assignment as merely a precatory reference to the need for the school board to take steps to correct the racially imbalanced system then existing, and therefore the order was not seen as operating to curtail board discretion."2 Similarly, the order to abolish the "track system" did not limit board discretion since that ability grouping method had been under severe attack and the board, even before the ruling, had taken steps to devise an improved method. ${ }^{13}$ No intervention was allowed since these rulings did not affect the parents' interest in maximum board discretion. Intervention was allowed to contest the rulings relating to bussing, optional zones and faculty integration because these orders required the board affirmatively to undertake new activities and to abolish features which were an accepted part of the school system." However, on the merits, these three rulings were found to be constitutionally required to remedy the discriminatory practices inherent in the board's previous methods. refused to modify any part of the order entered by the trial court.t5

Smuck 1 . Hobson is a logical extension of the District of Columbia Circuit's apparent decision to read broadly the El Paso interpretation of the "interest" requirement under rule 24(a)(2). Previously, in liuesse, the same court had defined the requisite interest by balancing the demands of apparently concerned parties with the need for judicial efficiency and due process. ${ }^{47}$ Smuck

${ }^{10} 1$. at 182. See gencrally. Shapiro. Some Thonghts on Intervention Before Courts, .tgencies, and .trbitrators. 81 HARv. L. REv. 721, 752-56 (1968).

" 408 F.2d at 182.

IId. at 186.

: Idl. at 187-90. For an extended discussion on the criticism of the District of Columbia's "track system," see Hobson v. Hansen, 269 F. Supp. 40I, 442-92 (D.D.C. 1967).

" 408 r.2d at 183-85.

sid.

${ }^{16}$ Itl. at 190. Since a new sehool board had been elected subsequent to the rulings in the trial court, the case was remanded to the lower court. instead of a simple affirmance, in order to insure that the new school board was given wide latitude in the development of new programs and orders pertaining to the school system.

"See note 25 supra. 
represents an excellent example of the application of the Viuesse rule. The parents had an appropriate concern for their children's welfare which could be affected by a decision limiting the board's discretion. Furthermore, overall efficiency would be improved since the contribution of the additional parties on appeal would be limited to briefs and oral arguments as opposed to a possibly drawn out trial court action on many of the same issues if the parents were forced to bring a separate lawsuit. Moreover, the actual interest found in Smuck is analogous to that present in Vuesse. In . Vuesse, a state official directly concerned with effectuating state policy had an "interest" in a controversy concerning the nature and protection of that policy's whereas in Smuck, parents directly concerned with protecting their children's welfare had an "interest" in a controversy concerning the protection of a policy directly related to their children's welfare." Going beyond the "economic" interest of El Paso. Smuck joins .'uesse in finding the requisite 24(a)(2) "interest" where adjudication between primary litigants will necessarily involve the interpretation of a policy which directly affects the intervenor's particular area of concern.

Intervention which is based upon the intervenor's interest in seeing that the court favorably determines certain facts and legal questions would seem, however, to fall within the scope of rule 24(b) which provides for intervention in the discretion of the trial court when "an applicant's claim or defense and the main action have a question of law or fact in common." "so The liberal interpretation of 24(a)(2) therefore represents an encroachment upon the scope of rule $24(\mathrm{~b})$, perhaps manifesting judicial disfavor with the practice of only allowing appeal from a denial of permissive intervention upon a final judgment $t^{\text {s1 }}$ and of limiting the scope of review on appeal to the question of abuse of discretion..$^{2}$

"Xee text accompanying note 25 supra.

10808 F.2d at 180 .

ज Fib. R. CIV. P. 24(b).

"See, e.g., City of New York v. Consolidated Gas Co., 253 U.S. 219 (1920); Burrow v. Citizens' State Bank, 74 F.2d 929 (5th Cir. 1935). But see Brotherhood of R.R. Trainmen v. Baltimore \& O.R.R.. 331 U.S. 519, 524-25 (1947). See genterall.' Shapiro, supra note 40, at $748-51$.

3: See. e.g.. Cameron v. President and Fellows of Harvard College, 157 F.2d 993, 997 (Ist Cir. 1946): Wolpe v. Poretsky, 144 F.2d 505, 508 (D.C. Cir.), cert. denied. 320 U.S. 777 (1944). 
Thus, Smuck. Nuesse and El Paso may presage a decreased use of permissive intervention with its attendant hardships. However, given the expanded scope of rule 24(a), Smuck may have its greatest value as a guide for easier judicial determination of when to allow intervention as of right. By broadening the scope of "interest" and viewing it as a minimum prerequisite rather than a determinative criterion,,$: 3$ courts no longer are confronted with having to decide a request for intervention primarily on the basis of the nebulous concept of "interest." in Instead, the major factors in allowing intervention become practical impairment and adequacy of representation, the meanings of which are perhaps more readily apparent. Since the purpose of intervention is to decide when existing litigation should be opened to additional parties,,$\overline{7}$ practical matters such as possible harm and adequate representation would seem better suited to such a purpose rather than a technical analysis of the proposed intervenor's "interest." Indeed, the 1966 amendments were passed in order to end such a technical interpretation of "bound by a judgment" and "inadequate representation." As Simuck notes, post-amendment courts should not be lead astray by a similar "myopic fixation" on the nature of an "interest." "si However, "interest" is not read out of rule 24(a)(2) by Smuck.js Instead of being the prime determinant in granting intervention, the minimum "interest," previously found, will be analyzed again to determine the scope of intervention. Such treatment would seem in accord with the Nuesse definition of interest since in determining the scope, the court would seek to allow intervention on as many related issues as compatible with efficient court operation. Unfortunately, the District of Columbia Circuit stands alone in its attempt to grant intervention in accord with the pragmatic considerations behind rule 24(a)(2) rather than on the abstract or technical character of "interest."

$=408$ F.2d at $179-80$.

"For an example of an attempt to classify "interests" see Shapiro, supra note 40, at 72940. Professor Shapiro concludes that the "range of possible interests may defy adequate classification, spreading over a spectrum that is extremely hard to chart." Id. at 740.

is $408 \% .2 d$ at 179.

3 See Advisory Committee's Note, 39 F.R.D. 69. 110 (1966).

si 408 F.2d at 179.

is $I d$. at $179-80$. 